\section{Developmental health in the context of an early childhood program in Brazil: the "Primeira Infância Melhor" experience}

\author{
Saúde desenvolvimental no contexto de um \\ programa de primeira infância no Brasil: a \\ experiência do Primeira Infância Melhor
}

\section{Salud del desarrollo en el contexto de un programa de infancia temprana en Brasil: la experiencia "Primeira Infância Melhor"}

Tonantzin Ribeiro Gonçalves 1

Eric Duku 2

Magdalena Janus 2

\begin{abstract}
Design and evaluation of early child development (ECD) programs are poorly documented in low-or middle-income countries. The study aimed to identify family and child characteristics associated with developmental health outcomes among children aged from 4 to 6 years who participated in the "Primeira Infância Melhor" - PIM (Better Early Childhood), a home visiting program in Rio Grande do Sul State, Brazil. We also evaluated the impact of PIM on developmental vulnerability at school entry using a comparison group. Multistage sampling was first used to select cities, then families, in different regions of the state, resulting in a sample of eight cities and 571 children (364 PIM; 207 comparison). We used a sociodemographic questionnaire, completed by parents, and the Early Development Instrument (EDI), completed by teachers. Among PIM children, lower family income, time of exit from the program, city, and younger age were associated with higher risk of developmental vulnerability and/or with lower mean scores in EDI domains. Multivariate analysis controlling for covariates found no differences between the study groups in EDI outcomes even though the gaps in equity of the outcomes were smaller in the PIM group. These results are discussed in the context of challenges faced by home visiting programs in addressing complex social conditions of high-risk families and difficulties in finding an adequate comparison group in communities where an ECD program is universally accessible. We also note the importance of setting structured and longitudinal monitoring systems together with the implementation of ECD policies.
\end{abstract}

Child Development; Child Health; Home Care Services; Program Evaluation doi: 10.1590/0102-311X00224317

Correspondence

T. R. Gonçalves

Programa de Pós-graduação em Saúde Coletiva, Universidade do Vale do Rio dos Sinos.

Av. Unisinos 950, São Leopoldo, RS, 93020-190, Brasil. tonanrib@yahoo.com.br

1 Programa de Pós-graduação em Saúde Coletiva, Universidade do Vale do Rio dos Sinos, São Leopoldo, Brasil. 2 Offord Center for Child Studies, McMaster University, Hamilton, Canada. 


\section{Introduction}

Early child development (ECD) is a foundation for adult well-being and population health. Growing scientific evidence highlights the long-lasting consequences of events or experiences that occur in the early childhood for both physical and neurobiological systems that guide physiological and behavioral responses to stress during an individual's life 1,2. Poor early health burdens society with significant social and economic costs related to the development of chronic diseases, mental health problems, and other functional disabilities ${ }^{3}$. ECD is strongly influenced by both social and biological determinants: children raised in the poorest communities, facing nutritional and sanitary disadvantage, and exposure to crime and violence show the worst school performance, among many other negative outcomes, preventing them to fulfill their developmental potential 2. The lack of opportunities for healthy development is also related to higher levels of unemployment, involvement with criminal acts, drug use and poor health and well-being in adult life 1 . This phenomenon of association between socioeconomic factors and outcomes is not confined to health only, but rather is evident for a whole range of developmental outcomes as well. This led Keating \& Hertzman 4 to use the term "developmental health" to indicate a full range and holistic view of outcomes encompassing medical aspects (freedom from disease and delays) as well as physical, social and emotional ones.

Considering this growing body of evidence, the promotion of healthy ECD is a core priority to attain a more equitable, fair and wealthy society. Investments in the care for pregnant women, infants, and young children are widely supported as "the most cost-effective means to reduce poverty and to foster economic growth" 3 (p. 2). Comprehensive and culturally relevant ECD interventions are designed to avoid or cut down the physical, cognitive, and emotional limitations faced by children experiencing social disadvantage 5,6 .

Many different attempts to enhance ECD have emerged around the world, but a relatively small number of them hold promising and sustainable results. For example, even though most of ECD center-based, public funded programs show positive effects in cognitive outcomes such as academic achievement, school readiness tests, IQ, and grade retention among disadvantaged US children aged from 3 to 5 years, similar impact was not found for social cognition, social risk behaviors, child health and family outcomes 6 . Three rigorously studied ECD programs show a range of considerable gains: the Perry Preschool Project, the Abecedarian Project, and the Nurse-Family Partnership 7. Particularly, the Perry Preschool Project, which assessed participants until the age of 40 years, reported positive impact on high school graduation, employment status, home ownership, teen pregnancies, delinquency, arrests and welfare dependency use 8 . Disadvantaged children who participated in the Abecedarian Project showed significantly lower prevalence of risk factors for cardiovascular and metabolic diseases in adulthood, especially among males 9 . Despite their success, the intensity of such programs does not lend itself easily to scaling up and sustainability 10.

In light of this evidence, it is important to explore characteristics of the ECD programs, as well as the characteristics of children and families that may contribute to the higher impact and effectiveness of the interventions. Features of ECD programs, such as health service provision, and focus on responsible caregiving as well as safe and language-rich environments showed meaningful results in promoting child development outcomes 5,7. Evidence also reinforces the importance of the maintenance of program standards, ongoing training and assistance to the intervention providers, as well as continued quality monitoring and improvement to ensure the effectiveness of population programs and services targeting diverse needs of ECD 11. Indeed, lack of fidelity in program implementation could be a factor contributing to its limited success 11 . Children and families in poverty seem to benefit more from broad programs that combine center-based care, social welfare and education for both children and parents 7 .

A specific form of ECD-focused intervention is related to home visiting programs (HVP). HVP involve regularly scheduled visits at a family home and the care is delivered by trained workers, professionals or paraprofessionals. The targets are often (though not always) households with pregnant women, and the visits continue after the baby is born. HVP are designed to provide facilitated access to services and guidance, offering a combination of direct information or service provision and referral to community resources 12,13 . The HVP delivered by paraprofessionals were more effective because they focused on a particular ECD issue, offered a higher and long-term dose of the inter- 
vention, started prenatally and provided adequate training and support for the staff 14 . HVP also demonstrated positive results in prevention of child abuse 12,13, increase of the use of prenatal care 15, decrease in health problems in older children, as well as improvement in appropriate weight gains in early childhood ${ }^{14}$. Among 33 HVP evaluated, those most cost-effective in preventing child maltreatment were led by professionals in multidisciplinary teams, targeting high risk families and including comprehensive interventions (e.g., social work intervention, housing support, parenting groups) 16. Nevertheless, systematic reviews also showed limited effectiveness of HVP in preventing developmental delays and premature birth, or improving birth weight and health outcomes of children from socially disadvantaged families 14,15 .

The majority of the evidence-based ECD programs were not developed or evaluated in low- or middle-income countries 6,14. An exception is a well-studied HVP developed in Jamaica during the late 1980s targeting 129 malnourished children aged from 9 to 24 months for two years. Positive results were found for cognitive development, IQ, educational attainment and earnings during adulthood 17. This study highlighted the importance of implementing and evaluating ECD strategies in contexts where most of the children in social disadvantage around the world live.

Brazil has been classified as an upper-middle income country and, in the past three decades, has experienced dramatic improvements in child health and nutrition levels, achieving a reduction of $50 \%$ in the number of underweight children and a two-thirds decrease in mortality rate among children under 5 years old 18, which reached 15.7 deaths per 1,000 live births in 2012 19. This progress was mainly driven by key changes in social determinants (i.e., poverty, education of women, urbanization, and fertility), non-health-sector interventions, and the implementation of national health system based on the spread of primary health care provision since the 1980s 18. This, in turn, has raised issues about how those economic improvements are affecting children and mitigating social inequalities in early life.

Considering children's access to education, the most recent representative national survey indicated an increasing level of frequency of school attendance in Brazil, especially among children under 5 years of age 19. The Brazilian National Plan for Education 2014-2024 established that all children aged from 4 to 5 years should be enrolled at school by 2016. Even though recent national policies are promising, in 2014, about $17.3 \%$ of 4 - and 5-year-old children had not yet started school 20 and the poorest children were less likely to be enrolled in a formal education 21. Therefore, it is important to examine what effect the ECD policies in Brazil may have on children's development at school entry.

A pioneering intervention targeting ECD in Brazil is the "Primeira Infância Melhor" - PIM (Better Early Childhood), a program launched in 2003 in the State of Rio Grande do Sul. The PIM was inspired by the Cuban program "Educa a Tu Hijo" 22 and was developed with the local support of the state and municipal governments, as well as the international support from the United Nation Educational, Scientific and Cultural Organization (UNESCO) and the United Nations Children's Fund (UNICEF). In 2006, PIM was established as a state policy for the promotion and development of early childhood, specially focusing on pregnant women and children less than three years old living in socially vulnerable areas. Until August 2017, PIM had reached $50 \%$ of the cities in the state. More than 2,600 home visitors are supporting 8,070 pregnant women and 59,180 children and their families (PIM. http://www.pim.saude.rs.gov.br/v2/o-pim/dados/23, accessed on 11/Oct/2017).

This study aimed to identify family and child characteristics associated with developmental health outcomes (that is, a broad range of skills and behaviors) among children from 4 to 6 years old who participated in PIM before school entry. Also, the type of participation (individual and/or group attendance), the length of exposure to the program and the different cities where it was delivered were assessed for their contribution to children's developmental health in PIM. First, we expected that children who participated in PIM longer and who started at an earlier age would show better developmental health outcomes. Conversely, those who came from more socially vulnerable families (e.g., less educated parents and low income families) would show lower levels of developmental vulnerability. Second, we intended to evaluate the impact of PIM in school readiness and in reducing levels of developmental vulnerability at school entry using a comparison group of children who have never participated in any other educational intervention before school entry. 


\section{Methods}

\section{Intervention background}

PIM aims to "provide guidance to families, based on their own culture and experiences, to allow them to promote their children's holistic development from pregnancy to six years old" 23 (p. 23). The conceptual model of PIM combines Vygotsky's sociocultural approach, Piaget's theory of learning, neurodevelopmental evidence and attachment theory. PIM assists families through individual and group modalities, complemented by a community-based approach which integrates education, health and social services at municipal level 23.

Until the child is 3 years old, families receive an one-hour visit per week ${ }^{23}$. In the group modality, families with children aged from 3 to 6 years are invited to attend weekly meetings in community spaces. Pregnant women receive home visits every two weeks and are invited to attend a monthly group modality to benefit from information about child delivery, breastfeeding, and other healthrelated issues promoting experience sharing. All families receive a guide book which summarizes the PIM approach and provides health reminders and activity recommendations designed to enhance child development. Besides the weekly home visits targeting parenting guidance and issues related to the family's health and well-being, PIM leads and supports other actions such as early literacy and recreational activities, allocation of resources to vulnerable families (e.g., registering families in social programs), community workshops and neighborhood mobilization on ECD and reducing violence issues.

Visitors usually have a formal education in health, education or social welfare, and have completed a 40-hours training on the PIM model of care, up-to-date child development, and skills including how to interact with parents and children, and cultural sensitivity. The core PIM activities with the families are manualized in a guide book distributed to all staff, based on which visitors develop an adapted schedule with activities for each family considering their needs and the children's age, as well as cultural aspects and local capacity 23 . Each visitor is in charge of up to 20 families and participates in a weekly supervision group. At the state level, public servants, specialized consultants, regional health and education representatives comprise an interdisciplinary technical advisory group whose role is to coordinate training, monitoring, and implementation of PIM activities in the municipalities, and to support local networking on matters related to child development. Professionals from the technical group have bachelors' or graduate degrees in areas such as medicine, psychology, nursing, education, social welfare, speech therapy, public health, and administration.

Visitors undertake regular monitoring of the child's developmental progress using key developmental behavioral indicators in cognitive, motor, socio-affective and language areas. This assessment underwent content and cultural validation, but has no full psychometric validity. An initial child and/ or family assessment was not routinely implemented by PIM before 2007.

\section{Study procedures and sample}

A multistage sampling procedure with selection of families within the state of Rio Grande do Sul was developed. Among 496 cities in Rio Grande do Sul, almost 50\% $(n=247)$ had implemented PIM in 2011. To guarantee the presence of children from 4 to 6 years who received a minimum investment in early child care, only the cities where PIM was implemented at least six years before the data collection were included in the first sampling stage. Subsequently, the stratification was based on the Mahalanobis distance calculation 24 , which is a measurement of the diminishing association among various important characteristics of the cities and the same measures for the whole state. The first measure used the following variables to calculate the Mahalanobis distance: (1) Social Exclusion Index 25; (2) Child Development Index (CDI) 26; (3) Municipal Human Development Index (MHDI) in Brazil, 2006 (United Nations Development Programme. http://www.atlasbrasil.org.br/2013/pt/28, accessed on 01/Aug/2017). The second measure of distance added the percentage of early child education coverage among all children from 0 to 6 years old and the last one added the percentage of children from 0 to 6 among total city population. The three measures were highly consistent and were used to select eight cities in different regions whose characteristics were most representative of the state: Alegrete, 
Carazinho, Frederico Westphalen, Palmeira das Missões, Santiago, Santo Ângelo, São Borja, and Uruguaiana. Among these cities, six had more than 50,000 inhabitants ( $70 \%$ of the total population of the state lives in cities with more than 50,000 inhabitants) and two had around 30,000 inhabitants at the time of the study. Cities included had implemented PIM in the very early years of the program: six of them during the first two years (2003-2004) and other two, in the subsequent years (2005-2006).

In the final stage of sampling process, a list of eligible children enrolled in PIM for each city was generated from the program database. This comprised 2,359 children who left the program after at least 11 months of participation, and who were from 4 to 6 years old during the time the recruitment happened (July to September, 2011). The aim was to include around 1,000 families in the study with two-thirds in the PIM group. However, for a family to be approached for participation, their address had to be updated, and the child had to be in the first year of school, which was checked by consulting the official schools registers. Based on these two criteria, $77 \%$ of the potentially available PIM families were not eligible for the study (Supplementary Material 1; http://cadernos.ensp.fiocruz.br/site/ public_site/arquivo/supplementary-material-1_5776.pdf).

Teachers in classrooms with PIM children invited families to participate in the study for comparison purposes. For the comparison group, only children who were in the first year of school and had not attended any other education program before were eligible. This resulted in almost all children meeting the comparison criteria in the classroom of PIM children being invited and participated in this study. When children could not be recruited, for the comparison group in the class, a child in another class of the same grade at the school was included. Five families and two teachers refused to participate and 14 did not meet several inclusion criteria. The final analytic sample of 571 included children with data on all variables required for the analyses (Supplementary Material 1; http://cader nos.ensp.fiocruz.br/site/public_site/arquivo/supplementary-material-1_5776.pdf).

A pilot implementation study was conducted from May to June 2011 to examine the psychometric properties of the Portuguese version of the instrument for measuring child development (Early Development Instrument - EDI) and to adjust procedures related to recruiting process, teachers and interviewers' training. Data collection for the main study was carried out between July and September 2011 for all cities after reviewing the results of the pilot data. All identified families were visited at home by trained PIM visitors or supervisors and the main child caregivers were invited to complete a sociodemographic questionnaire. Most frequently the mothers and/or fathers were interviewed but, in a few cases, the main caregiver was a grandmother/grandfather, a stepmother/stepfather or an aunt/uncle. Each interview lasted approximately 30 minutes and families received no reimbursement for their participation.

Teachers were trained in completion of the EDI by trainers who participated in a 10-hour workshop run by the developer of the instrument with the PIM staff in March 2011. Data collection was done by PIM staff under the coordination of an independent researcher (T.R.G.). All data were checked for unusual or out-of-range values. Double data entry performed with $10 \%$ of the instruments showed a very high level of consistency.

The project was approved by the Ethics Research Committee of the School of Public Health of the Rio Grande do Sul State and written informed consent was provided by each family and teacher.

\section{Measures}

\section{- Sociodemographic questionnaire}

Families were asked to provide data about the child, including date of birth, sex, ethnicity, whether the child lived together with the biological mother and/or father, level of education and occupation for both parents. Information was also collected on daily child care, number of siblings and family income.

Family income per capita was calculated as the ratio of the reported family income and the number of people in the household. The ratios were categorized as follows: $\leq$ BRL 140, BRL 141-270 and $\geq$ BRL 271 per person. The years of maternal education were classified into three categories: 4 years or less, 5 to 8 years, and 9 or more years. Ethnicity was reclassified as white, black and other (e.g., Indigenous, Asian). 


\section{- EDI Portuguese version}

The EDI is a teacher-completed measure of children's developmental health at school entry 27 . The 103 items of the EDI cover five domains: (i) Physical Health and Well-being; (ii) Social Competence; (iii) Emotional Maturity; (iv) Language and Cognitive Development; and (v) Communication Skills and General Knowledge. The EDI has been shown to have good validity and reliability in original studies developed with Canadian population, and in other English-speaking countries 27,28. The EDI provides a score for each domain ranging from 0 to 10 and an overall vulnerability score which indicates children classified as "vulnerable" in at least one domain. Vulnerability on a domain is defined as having a score lower than the score at the 10th percentile cut-point of the domain based on a normative reference population.

The English EDI version was adapted into Portuguese and the back-translation process was conducted by experts in child development 29 . The Portuguese EDI version was used in a pilot study for our study with a sample of 78 children in their first year at school: 39 who had participated in PIM before school entry and 37 who had not received any specialized child care before school entry. The results from the pilot study indicated that the instrument had adequate psychometric properties and also showed good test-retest reliability in all domains, as indicated by the paired correlations which were all greater than 0.8 .

\section{- Intervention (only for former PIM participants)}

Data from the PIM database were obtained for each child regarding the length of time spent in the program ( $\leq 24$ months vs. $>24$ months) and how many visitors took care of the child during her/his time in PIM (1 vs. 2 or more).

The child's age at starting in PIM was categorized as before age one or after. Before the age of 3, children usually participated in the PIM Individual Modality through home visiting and, after that, families were assisted in the group modality. The child's age at PIM exit was categorized as prior to completion at 55 months of age, or after.

\section{Data analysis}

Exploratory data analyses by study group and further classified by other child/family characteristics were performed. Internal consistencies of the EDI domains were examined using Cronbach's $\alpha$, which showed that all five domains of the EDI had good internal consistency: Physical Health and Well-being (0.774); Social Competence (0.958); Emotional Maturity (0.927); Language and Cognitive Development (0.913); and Communication Skills and General Knowledge (0.920).

Statistical analyses of the differences between the study groups were examined using contingency tables. Effect sizes of the differences between PIM and comparison were calculated as follows: mean (comparison/PIM group) - mean (reference/comparison group) divided by standard deviation (reference/comparison group). Next, multivariate analysis of variance (MANOVA) was used to examine study group differences on the EDI domains controlling for the effects of covariates. Binary logistic regression was also used to evaluate the risk of overall vulnerability on the EDI in the PIM group controlling for covariates.

Finally, for the children that attended PIM, we performed a descriptive analysis of the covariates, including city of residence, family income per capita, mother's years of education, age at entry into PIM, and age at exit from PIM. We then used MANOVA to examine the relationship of these correlates with the EDI domains controlling for child's sex and age and then examined the effects of the correlates of overall vulnerability on the EDI using binary logistic regression. All analyses were carried out using SPSS version 24.2 (https://www.ibm.com/). 


\section{Results}

\section{Sociodemographic characteristics and EDI scores}

Table 1 shows descriptive statistics for the sociodemographic characteristics and EDI domain scores by study group. The distribution of the children by city shows that there were differences in percentages of participants by study group. A larger percentage of participants in the PIM group came from families with income per capita less than or equal to BRL 140 (42.3\%) compared to the comparison group (38.5\%). Still, a greater percentage of participants in the comparison group (42.6\%) were from families with income per capita over BRL 200 compared to the PIM group (38.5\%). There were no meaningful differences in other demographic aspects, although both children and mothers in the comparison group were slightly older than those in the PIM group.

The overall vulnerability on EDI for the whole sample was $26.4 \%$ (Table 1). There were no differences in the mean EDI domain scores between the two groups. However, in all domains but Emotional Maturity the scores were somewhat higher for children in PIM than in the comparison group (Table 1).

\section{Developmental health in PIM children versus comparison group}

In both groups, boys were more likely to be vulnerable than girls (Table 2). However, the difference between the sexes was smaller for the PIM group (7.4\%) compared to the comparison group (15.4\%). The overall vulnerability rate was higher for children with family income per capita between BRL 141 to 200 and lower for those with family income per capita greater than BRL 200. Table 2 shows that the gaps in vulnerability rates between family income per capita groupings are smaller for the PIM group compared to the comparison one. For mother's education, the lowest overall vulnerability rate was observed in both study groups for children who came from families with mothers that had 9 or more years of schooling. However, it should be noted that the highest overall vulnerability rates were observed for children in the PIM group in the other race group, and with mothers that had 4 or fewer years of schooling, respectively. For the comparison group, the highest overall vulnerability rates were observed for children with family income per capita between BRL 141 to 200, and with mothers that had 5 to 8 years of schooling, respectively.

Results of the MANOVA showed no significant differences when controlling for other covariates between the study groups in mean scores for the five EDI domains. Meanwhile, sex, city, and family income were significantly associated with EDI scores for all children (Supplementary Material 2; http://cadernos.ensp.fiocruz.br/site/public_site/arquivo/supplementary-material-2_4063.pdf).

Logistic regression was used to determine the risk of vulnerability by group, controlling for age at completion; family income; city, group, mother's education, child's sex (Table 3). Results show no significant association with being in the PIM compared to the comparison group $(\mathrm{OR}=0.817$; $95 \% \mathrm{CI}$ : $0.536-1.246 ; \mathrm{p}=0.347$ ). The analyses showed that being a boy, having lower family income, and living in Carazinho were associated with higher risk of developmental vulnerability.

\section{Characteristics associated with developmental health among PIM children}

Supplementary Material 3 (http://cadernos.ensp.fiocruz.br/site/public_site/arquivo/supplemen tary-material-3_2975.pdf) presents descriptive analyses for the scores from EDI domains and overall vulnerability by the possible covariates among PIM group. The proportions of participating children were the smallest for Alegrete (1.6\%) and the largest for the cities of Frederico Westphalen (19.8\%) and Santiago (19.5\%). Most mothers of children who attended PIM had 5 to 8 years of schooling (52.5\%), followed by 9 years of schooling or more (31.9\%). It was also observed that most children that attended PIM had only one visitor (94.8\%), most of them participated in the group modality (72.3\%), and started PIM when they were older than 12 months (61.5\%). The city of Carazinho had the highest percentage $(33.8 \%)$ of children with developmental vulnerability while the city of Santo Ângelo had the lowest percentage (15.9\%).

The MANOVA for children who attended PIM $(n=364)$ showed that city, age at EDI implementation and age at exit from PIM ( $\leq 55$ months vs. $>55$ months) were significantly associated with EDI 
Table 1

Sociodemographic characteristics, Early Development Instrument (EDI) scores and effect sizes of group differences for the selected sample of children from "Primeira Infância Melhor" (PIM) and comparison groups.

\begin{tabular}{|c|c|c|c|c|c|}
\hline & $\begin{array}{c}\text { Total } \\
(N=571)\end{array}$ & $\begin{array}{l}\text { PIM group } \\
(\mathrm{n}=364)\end{array}$ & $\begin{array}{c}\text { Comparison group } \\
\quad(n=207)\end{array}$ & Effect size & Test statistic; p-value \\
\hline Age of child [mean (SD)] & $5.73(0.69)$ & $5.69(0.66)$ & $5.80(0.75)$ & 0.147 & $2.963 * ; 0.086$ \\
\hline Persons in the family (including the child) [mean (SD)] & $4.59(1.51)$ & $4.64(1.51)$ & $4.49(1.49)$ & -0.101 & $1.266 * ; 0.261$ \\
\hline Siblings who live with the child [mean (SD)] & $1.48(1.46)$ & $1.55(1.49)$ & $1.36(1.40)$ & -0.136 & $2.226 * ; 0.136$ \\
\hline Mother or main caregiver's age [mean (SD)] & $32.15(8.13)$ & $31.95(8.07)$ & $32.50(8.25)$ & 0.067 & $0.607 * ; 0.436$ \\
\hline Sex [\%] & & & & & $0.602 * *$ \\
\hline Female & 50.1 & 49.2 & 51.7 & - & \\
\hline Male & 49.9 & 50.8 & 48.3 & - & \\
\hline Race [\%] & & & & & $\chi^{2}(2)=2.954 ; 0.228$ \\
\hline White & 77.5 & 75.3 & 81.5 & - & \\
\hline Brown & 19.8 & 21.9 & 16.1 & - & \\
\hline Other (e.g. Indigenous, Asian) & 2.7 & 2.8 & 2.4 & - & \\
\hline Family income per capita (BRL) [\%] & & & & & $\chi^{2}(2)=7.732 ; 0.021$ \\
\hline$\leq 140$ & 38.5 & 42.3 & 31.9 & - & \\
\hline $141-200$ & 18.9 & 19.2 & 18.4 & - & \\
\hline$\geq 201$ & 42.6 & 38.5 & 49.8 & - & \\
\hline Mother's schooling years [\%] & & & & & $\chi^{2}(2)=0.397 ; 0.820$ \\
\hline$\leq 4$ & 15.2 & 15.7 & 14.5 & - & \\
\hline $5-8$ & 52.0 & 52.5 & 51.2 & - & \\
\hline$\geq 9$ & 32.7 & 31.9 & 34.3 & - & \\
\hline Parents live together [\%] & 76.0 & 77.2 & 73.9 & - & 0.415 ** \\
\hline City [\%] & & & & & $\chi^{2}(7)=38.255 ;<0.001$ \\
\hline Frederico Westphalen & 15.2 & 19.8 & 7.2 & - & \\
\hline Carazinho & 20.7 & 17.9 & 25.6 & - & \\
\hline São Borja & 14.0 & 12.9 & 15.9 & - & \\
\hline Santo Ângelo & 14.4 & 12.1 & 18.4 & - & \\
\hline Uruguaiana & 5.8 & 7.4 & 2.9 & - & \\
\hline Santiago & 16.6 & 19.5 & 11.6 & - & \\
\hline Alegrete & 1.8 & 1.6 & 1.9 & - & \\
\hline Palmeira das Missões & 11.6 & 8.8 & 16.4 & - & \\
\hline Overall vulnerability in EDI [\%] & 26.4 & 26.1 & 27.1 & - & \\
\hline \multicolumn{6}{|l|}{ Scores on EDI domains *** [mean (SD)] } \\
\hline Physical Health and Well-Being & $8.92(1.39)$ & $8.93(1.37)$ & $8.89(1.44)$ & -0.028 & $0.146 * ; 0.702$ \\
\hline Social Competence & $8.41(1.80)$ & $8.44(1.73)$ & $8.35(1.90)$ & -0.047 & $0.366 * ; 0.545$ \\
\hline Emotional Maturity & $7.90(1.66)$ & $7.84(1.70)$ & $7.99(1.58)$ & 0.095 & $1.102 * ; 0.294$ \\
\hline Language and Cognitive Development & $6.13(2.30)$ & $6.14(2.25)$ & $6.11(2.39)$ & -0.013 & $0.017 * ; 0.895$ \\
\hline Communication Skills and General Knowledge & $7.74(2.50)$ & $7.78(2.52)$ & $7.67(2.47)$ & -0.045 & $0.234 * ; 0.629$ \\
\hline
\end{tabular}

SD: standard deviation.

* ANOVA test; $F(1,569)$;

** Fisher's exact test (two-sided):

*** EDI scores ranging from 0 to 10 . 
Table 2

Overall vulnerability on Early Development Instrument (EDI) by covariates among children from "Primeira Infância Melhor" (PIM) and comparison groups.

\begin{tabular}{|c|c|c|c|}
\hline & $\begin{array}{l}\text { PIM group (\%) } \\
\quad(n=364)\end{array}$ & $\begin{array}{l}\text { Comparison group (\%) } \\
\qquad(\mathrm{n}=207)\end{array}$ & p-value * \\
\hline \multicolumn{4}{|l|}{ Gender } \\
\hline Female & 22.3 & 19.6 & 0.423 \\
\hline Male & 29.7 & 35.0 & 0.656 \\
\hline \multicolumn{4}{|l|}{ Age group } \\
\hline$\leq 5.71$ & 24.9 & 29.8 & 0.396 \\
\hline$>5.71$ & 27.5 & 24.8 & 0.679 \\
\hline \multicolumn{4}{|l|}{ Race } \\
\hline White & 24.7 & 26.9 & 0.652 \\
\hline Brown & 29.1 & 30.3 & 1.000 \\
\hline Other & 40.0 & 20.0 & 0.600 \\
\hline \multicolumn{4}{|c|}{ Family income per capita (BRL) } \\
\hline$\leq 140$ & 29.9 & 33.3 & 0.635 \\
\hline $141-200$ & 32.9 & 44.7 & 0.297 \\
\hline$\geq 201$ & 18.6 & 16.5 & 0.736 \\
\hline \multicolumn{4}{|c|}{ Mother's schooling years } \\
\hline$\leq 4$ & 33.3 & 26.7 & 0.629 \\
\hline $5-8$ & 27.7 & 32.1 & 0.506 \\
\hline$\geq 9$ & 19.8 & 19.7 & 1.000 \\
\hline
\end{tabular}

Table 3

Results of logistic regression for the selected sample of children from "Primeira Infância Melhor" (PIM) and comparison groups examining risk of overall vulnerability on the Early Development Instrument (EDI) controlling for covariates $(\mathrm{N}=571)$.

\begin{tabular}{|c|c|c|c|c|c|}
\hline & B & SE & OR & $95 \% \mathrm{Cl}$ & p-value \\
\hline Group (PIM) & -0.20 & 0.22 & 0.82 & $0.54-1.25$ & 0.347 \\
\hline Sex (male) & 0.71 & 0.20 & 2.04 & $1.37-3.05$ & $<0.001$ \\
\hline Age group $\leq 5.71$ years & 0.15 & 0.20 & 1.17 & $0.78-1.74$ & 0.450 \\
\hline \multicolumn{6}{|l|}{ Income groups (BRL) } \\
\hline$\leq 140$ & 0.77 & 0.25 & 2.17 & $1.34-3.52$ & 0.002 \\
\hline $141-200$ & 1.09 & 0.27 & 2.96 & $1.74-5.04$ & $<0.001$ \\
\hline \multicolumn{6}{|c|}{ Mother's education groups (years) } \\
\hline $0-4$ & 0.57 & 0.32 & 1.77 & $0.94-3.33$ & 0.077 \\
\hline $5-8$ & 0.48 & 0.25 & 1.61 & $1.00-2.61$ & 0.052 \\
\hline \multicolumn{6}{|l|}{ City } \\
\hline Frederico Westphalen & 0.47 & 0.42 & 1.60 & $0.71-3.62$ & 0.260 \\
\hline Carazinho & 1.08 & 0.39 & 2.93 & $1.36-6.32$ & 0.006 \\
\hline São Borja & 0.68 & 0.42 & 1.98 & $0.86-4.55$ & 0.106 \\
\hline Santo Ângelo & 0.33 & 0.42 & 1.38 & $0.61-3.13$ & 0.436 \\
\hline Uruguaiana & 0.76 & 0.50 & 2.15 & $0.80-5.76$ & 0.130 \\
\hline Santiago & 0.52 & 0.42 & 1.69 & $0.74-3.87$ & 0.217 \\
\hline Alegrete & 0.71 & 0.78 & 2.03 & $0.44-9.44$ & 0.367 \\
\hline
\end{tabular}

95\%Cl: 95\% confidence interval; OR: odds ratio; SE: standard error. 
Table 4

Multivariate analysis of variance (MANOVA) results for the selected sample of children from "Primeira Infância Melhor" (PIM) group only $(n=364)$.

\begin{tabular}{|c|c|c|c|c|c|}
\hline Covariates by EDI domains & & $\begin{array}{l}\text { Type III sum of } \\
\text { squares (df) }\end{array}$ & Mean square & $\mathbf{F}$ & p-value \\
\hline \multirow[t]{5}{*}{ Sex * } & Physical Health \& Well-Being & $1.888(1)$ & 1.888 & 1.045 & 0.307 \\
\hline & Social Competence & $13.787(1)$ & 13.787 & 4.906 & 0.027 \\
\hline & Emotional Maturity & $17.796(1)$ & 17.796 & 6.525 & 0.011 \\
\hline & Language and Cognitive development & $18.975(1)$ & 18.975 & 4.529 & 0.034 \\
\hline & Communication Skills and General Knowledge & $23.876(1)$ & 23.876 & 3.949 & 0.048 \\
\hline \multirow[t]{5}{*}{ City ** } & Physical Health \& Well-Being & $14.498(7)$ & 2.071 & 1.146 & 0.334 \\
\hline & Social Competence & $45.655(7)$ & 6.522 & 2.321 & 0.025 \\
\hline & Emotional Maturity & $51.033(7)$ & 7.290 & 2.673 & 0.010 \\
\hline & Language and Cognitive Development & $102.199(7)$ & 14.600 & 3.485 & 0.001 \\
\hline & Communication Skills and General Knowledge & $21.18(7)$ & 3.026 & 0.500 & 0.834 \\
\hline \multirow[t]{5}{*}{ Income levels * } & Physical Health \& Well-Being & $5.007(2)$ & 2.504 & 1.385 & 0.252 \\
\hline & Social Competence & $6.465(2)$ & 3.233 & 1.150 & 0.318 \\
\hline & Emotional Maturity & $3.11(2)$ & 1.555 & 0.570 & 0.566 \\
\hline & Language and Cognitive Development & $19.053(2)$ & 9.526 & 2.274 & 0.104 \\
\hline & Communication Skills and General Knowledge & $21.397(2)$ & 10.698 & 1.769 & 0.172 \\
\hline \multirow[t]{5}{*}{ Mother's education groups * } & Physical Health \& Well-Being & $16.355(2)$ & 8.178 & 4.524 & 0.011 \\
\hline & Social Competence & $19.014(2)$ & 9.507 & 3.383 & 0.035 \\
\hline & Emotional Maturity & $15.487(2)$ & 7.744 & 2.839 & 0.060 \\
\hline & Language and Cognitive Development & $29.046(2)$ & 14.523 & 3.466 & 0.032 \\
\hline & Communication Skills and General Knowledge & $67.411(2)$ & 33.706 & 5.574 & 0.004 \\
\hline Intervention (individual vs. & Physical Health \& Well-Being & $0.003(1)$ & 0.003 & 0.002 & 0.967 \\
\hline \multirow[t]{4}{*}{ group) * } & Social Competence & $2.105(1)$ & 2.105 & 0.749 & 0.387 \\
\hline & Emotional Maturity & $2.24(1)$ & 2.240 & 0.821 & 0.365 \\
\hline & Language and Cognitive Development & $1.245(1)$ & 1.245 & 0.297 & 0.586 \\
\hline & Communication Skills and General Knowledge & $3.249(1)$ & 3.249 & 0.537 & 0.464 \\
\hline Age at start of PIM ( $\leq 12$ vs. $>$ & Physical Health \& Well-Being & $0.0(1)$ & 0.000 & 0.000 & 0.989 \\
\hline \multirow[t]{4}{*}{12 months) * } & Social Competence & $7.064(1)$ & 7.064 & 2.514 & 0.114 \\
\hline & Emotional Maturity & $0.636(1)$ & 0.636 & 0.233 & 0.629 \\
\hline & Language and Cognitive Development & $0.204(1)$ & 0.204 & 0.049 & 0.826 \\
\hline & Communication Skills and General Knowledge & $1.266(1)$ & 1.266 & 0.209 & 0.648 \\
\hline Time in PIM $(\leq 24$ vs. $>24$ & Physical Health \& Well-Being & $0.871(1)$ & 0.871 & 0.482 & 0.488 \\
\hline \multirow[t]{4}{*}{ months) * } & Social Competence & $0.385(1)$ & 0.385 & 0.137 & 0.711 \\
\hline & Emotional Maturity & $0.074(1)$ & 0.074 & 0.027 & 0.870 \\
\hline & Language and Cognitive Development & $0.032(1)$ & 0.032 & 0.008 & 0.930 \\
\hline & Communication Skills and General Knowledge & $0.497(1)$ & 0.497 & 0.082 & 0.775 \\
\hline Number of visitors ( 1 vs. 2 & Physical Health \& Well-Being & $1.051(1)$ & 1.051 & 0.581 & 0.446 \\
\hline \multirow{4}{*}{ or 3) * } & Social Competence & $0.001(1)$ & 0.001 & 0.000 & 0.988 \\
\hline & Emotional Maturity & $1.75(1)$ & 1.750 & 0.642 & 0.424 \\
\hline & Language and Cognitive Development & $1.65(1)$ & 1.650 & 0.394 & 0.531 \\
\hline & Communication Skills and General Knowledge & $3.499(1)$ & 3.499 & 0.579 & 0.447 \\
\hline Age group ( $\leq 5.71$ vs. $>5.71$ & Physical Health \& Well-Being & $0.014(1)$ & 0.014 & 0.008 & 0.931 \\
\hline \multirow[t]{4}{*}{ years) $* \star \star$} & Social Competence & $0.047(1)$ & 0.047 & 0.017 & 0.897 \\
\hline & Emotional Maturity & $1.637(1)$ & 1.637 & 0.600 & 0.439 \\
\hline & Language and Cognitive Development & $79.207(1)$ & 79.207 & 18.905 & 0.000 \\
\hline & Communication Skills and General Knowledge & $1.304(1)$ & 1.304 & 0.216 & 0.643 \\
\hline Age at exit from PIM ( $\leq 55$ vs. > & Physical Health \& Well-Being & $4.881(1)$ & 4.881 & 2.700 & 0.101 \\
\hline \multirow[t]{4}{*}{55 months) \# } & Social Competence & $12.156(1)$ & 12.156 & 4.326 & 0.038 \\
\hline & Emotional Maturity & $12.732(1)$ & 12.732 & 4.668 & 0.031 \\
\hline & Language and Cognitive Development & $39.543(1)$ & 39.543 & 9.438 & 0.002 \\
\hline & Communication Skills and General Knowledge & $15.991(1)$ & 15.991 & 2.645 & 0.105 \\
\hline
\end{tabular}

EDI: Early Development Instrument.

* Results for these variables showed no significant associations with EDI domain scores;

** City: Wilks' lambda $=0.801 ; F(35,1436.887)=2.21, \mathrm{p}<0.001$

*** Age at EDI implementation: Wilks' lambda $=0.911 ; F(5,34)=6.663, p<0.001$;

\# Age at exit from PIM: Wilks' lambda $=0.968, F(5,34)=2.25, p=0.05$. 
domain scores. Child's sex, family income groups, mother's education groups, child's age at PIM start ( $\leq 12$ months vs. $>12$ months), length of time in PIM ( $\leq 24$ months vs. $>24$ months), modality of participation, and number of visitors during the participation in PIM were not significantly associated with EDI domain scores (Table 4).

Associations for overall vulnerability showed that taking into account the effects of other covariates, $\operatorname{sex}(\mathrm{OR}=1.67 ; 95 \% \mathrm{CI}$ : 1.00-2.78; $\mathrm{p}=0.05)$, lower income groups $(\mathrm{OR}=1.86$; 95\%CI: 1.01-3.41; $\mathrm{p}=0.04$ and $\mathrm{OR}=2.28 ; 95 \% \mathrm{CI}: 1.14-4.57 ; \mathrm{p}=0.02)$, and exiting from PIM before 55 months of age $(\mathrm{OR}=2.19$; $95 \% \mathrm{CI}: 1.15-4.18 ; \mathrm{p}=0.01)$ were significantly associated with a higher risk of vulnerability on one or more EDI domains (Table 5).

\section{Discussion}

The main goal of this study was to investigate family, child and program uptake characteristics that contributed to developmental health among children from 4 to 6 years old who participated in a universally available ECD program in the state of Rio Grande do Sul before school entry. The secondary goal was to compare the school readiness and developmental vulnerability of PIM participants with a comparison group which attended no ECD program before. Our investigation indicated that certain demographic, geographic, and perhaps implementation characteristics may impact developmental health. While there were no significant differences in children's development at school entry between the PIM and comparison groups, some of the gaps in equity of outcomes were smaller in the PIM group.

The EDI data for the whole sample showed a very similar distribution to that observed elsewhere in Brazil and other countries. Girls had higher scores than boys, older children had higher scores than

Table 5

Results of logistic regression examining correlates of overall vulnerability on the Early Development Instrument (EDI) among "Primeira Infância Melhor" (PIM) children and for covariates of interest $(n=364)$.

\begin{tabular}{|c|c|c|c|c|c|}
\hline & B & SE & OR & $95 \% \mathrm{Cl}$ & p-value \\
\hline Sex (male) & 0.51 & 0.26 & 1.67 & $1.00-2.78$ & 0.05 \\
\hline Age group ( $\leq 5.71$ years) & -0.17 & 0.28 & 0.84 & $0.49-1.45$ & 0.53 \\
\hline \multicolumn{6}{|l|}{ City (vs. Palmeira das Missões) } \\
\hline Frederico Westphalen & 0.40 & 0.54 & 1.49 & $0.52-4.26$ & 0.45 \\
\hline Carazinho & 0.56 & 0.57 & 1.76 & $0.58-5.35$ & 0.32 \\
\hline São Borja & 0.49 & 0.57 & 1.64 & $0.53-5.02$ & 0.38 \\
\hline Santo Ângelo & -0.40 & 0.65 & 0.67 & $0.19-2.39$ & 0.53 \\
\hline Uruguaiana & 0.33 & 0.63 & 1.39 & $0.40-4.81$ & 0.60 \\
\hline Santiago & -0.03 & 0.59 & 0.97 & $0.31-3.04$ & 0.95 \\
\hline Alegrete & 1.01 & 1.01 & 2.75 & $0.38-19.76$ & 0.31 \\
\hline \multicolumn{6}{|l|}{ Income groups (vs. > BRL 200) } \\
\hline$\leq 140$ & 0.62 & 0.31 & 1.86 & $1.01-3.41$ & 0.04 \\
\hline $141-200$ & 0.83 & 0.35 & 2.28 & 1.14-4.57 & 0.02 \\
\hline \multicolumn{6}{|c|}{ Mother's education groups (vs. > 8 years) } \\
\hline $0-4$ & 0.68 & 0.40 & 1.98 & $0.90-4.35$ & 0.09 \\
\hline $5-8$ & 0.41 & 0.31 & 1.50 & $0.81-2.78$ & 0.19 \\
\hline Intervention (individual) & 0.42 & 0.42 & 1.52 & $0.68-3.43$ & 0.31 \\
\hline Age at PIM start ( $\leq 12$ months) & 0.07 & 0.32 & 1.07 & $0.57-2.02$ & 0.82 \\
\hline Length of time in PIM ( $\leq 24$ months) & -0.11 & 0.33 & 0.89 & $0.47-1.71$ & 0.73 \\
\hline Visitors (2 or 3 ) & 0.09 & 0.70 & 1.10 & $0.28-4.32$ & 0.89 \\
\hline Age at exit from PIM ( $\leq 55$ months) & 0.79 & 0.33 & 2.20 & $1.15-4.18$ & 0.01 \\
\hline
\end{tabular}

95\% Cl: 95\% confidence interval; OR: odds ratio; SE: standard error. 
younger ones, and children from more affluent families and those with more educated mothers had higher scores than those in poorer families or those with less educated mothers, showing the embedded relation between child development and the social determinants 29,30,31. These children have also very similar scores to Canadian children of approximately the same age, except for the domain of Language and Cognitive Development, where the children in our study have markedly lower scores than Canadian children ${ }^{31}$. This difference is likely due to the study sample coming from families with less than optimal socioeconomic circumstances, in comparison to the Canadian one.

Among PIM participants, lower income, early exit from the intervention, and being younger at the time of EDI assessment were associated with higher risk of developmental vulnerability. As indicated by the literature, HVP are likely not sufficient in addressing complex social conditions of high-risk families, where a comprehensive and consistent social support system is required 14,32 . It is important that an HVP such as PIM can be integrated with other existing social protection and supportive networking, for example, combining the ECD promotion with income transfer programs 33 or with other local community strategies 5,34. The linkage between HVP and health services can also improve access to information and preventive care for more vulnerable families 5,13. Another possible explanation for our results is that even though PIM usually includes highly vulnerable families, the program's focus is broad. It can be that such an inclusiveness of the program is related to fewer results among the most at risk families, which tend to have widespread needs 16,34 .

Longer participation in PIM was associated with better outcomes. Other HVP also showed benefits associated with higher doses of the intervention and early enrollment 13,14 even when the main effects are mixed or not statistically significant. It is important to point out that most of the evidence of the HVP impact on child developmental outcomes is based on short term post-test assessments in highly-controlled studies 34 , in contrast to our study which was community-based, and in which several years could have elapsed since the end of the program. In fact, our findings indicate that there may be lasting and cumulative effects of the intervention.

City of residence was also associated with EDI outcomes, which may raise issues about differences in the implementation quality. The cities included had the PIM implemented during the first three years of the program (from mid-2003 to early-2006) when monitoring and supervision processes were still being developed. It is also important to consider that since PIM was established as a state policy in 2006, each municipality was responsible to hire visitors, monitors and supervisors for the program which may have resulted in differences among cities in the minimum qualification required as well as in their salary and contract terms. Very recent observational data comparing quality and fidelity of implementation in HVP developed in seven countries from Latin America and the Caribbean, including the PIM, pointed out some strengths and shortcomings 35. For example, visitors achieved good involvement of families doing the activities during the visits, but appeared to often provide poor explanations regarding the importance of such activities to child development, lack the necessary materials and rarely stimulate language development. This reinforces the need for developing systematic and valid strategies to assess implementation fidelity, as well as qualified monitoring and community support, which is critical to successful dissemination of ECD programs, as PIM, in community settings ${ }^{11}$. While implementation accuracy is paramount, it is also important to understand the results of HVP impact on ECD more broadly, as families vary widely according to their needs, adherence to program and their own goal-setting, home stability, as well as educational and work attainments 32 . Evidence indicates that inter-sectoral packages together with HVP have reached better results and cost-benefits than HVP alone 10,16,34.

The study also aimed to investigate effects of the intervention in health development and school readiness comparing children who have attended PIM and children in a comparison group. No differences between groups were found. Nevertheless, in the PIM group we found smaller gaps between children participating in the program, suggesting evidence of equity as found among other interventions 33,36. Lack of significant group differences may to some extent reflect the difficulties in finding and matching children for the comparison group. Many children participate in community-based programs, even if on an irregular basis. As disadvantaged socioeconomic circumstances tend to be overrepresented among families attending PIM, it was challenging to match the samples. It is also possible that lower income levels among PIM group created a more challenging and vulnerable context for overall early development; thus, without the program, these children would have scored consid- 
erably lower. However, this claim cannot be supported without longitudinal data. Our study further emphasizes the need to include standardized and consistent assessments of family and children's progress before and during program implementation, as indicated by previous studies 11 .

The major limitation of the study is its cross-sectional nature, as we cannot directly ascribe causality to our results. Longitudinal studies and/or randomized trials are needed to better elucidate PIM effects on developmental health among vulnerable families. Finally, even though the possibility of finding an adequate comparison group may not have been realistic in the locations of our study, the inability to measure the comparison group participants' exposure to early programming and services also limits the interpretation of our results.

In conclusion, the ECD initiatives are very poorly documented in the Brazilian context and therefore our study, as one of the very first to do so, aimed to explore characteristics contributing to young children's developmental health associated with a large-scale intervention. Despite bona fide attempts at high standards of methodological rigor, only modest contributions of PIM to developmental health outcomes were found. Yet, the findings highlight the importance of setting structured and longitudinal monitoring systems together with the implementation of ECD policies and programs which would allow for more accurate evaluation of their impact on children's development.

\section{Contributors}

T. R. Gonçalves, E. Duku and M. Janus were equally involved in the study design and concept. T. R. Gonçalves coordinated all phases of the data collection. E. Duku conducted statistical analysis and T. R. Gonçalves drafted the manuscript. All authors critically revised the manuscript and approved the final version.

\section{Additional informations}

ORCID: Tonantzin Ribeiro Gonçalves (0000-00030249-3358); Eric Duku (0000-0003-3599-3527); Magdalena Janus (0000-0001-7806-1696).

\section{Acknowledgments}

We specially thank all families that participated in the study. We acknowledge Dr. Rodrigo Pinto for his assistance in the sampling process, and Dr. Fernanda Torres de Carvalho for her support in planning the research logistics and data collection. Also, the authors thank all members of the PIM team that participated in training of the teachers, family selection, recruitment, and data collection. This study was funded by UNESCO (grant n. 914BRA1124).

\section{References}

1. Hertzman C, Power C. Child development as a determinant of health across the life course. Current Paediatrics 2004; 14:438-43.

2. Walker SP, Wachs TD, Grantham-McGregor S, Black MM, Nelson CA, Huffman SL, et al. Inequality in early childhood: risk and protective factors for early child development. Lancet 2011; 378:1325-38.

3. Young ME, Richardson LM. Early child development from measurement to action: a priority for growth and equity. Washington DC: The World Bank; 2007.

4. Keating DP, Hertzman C. Developmental health and the wealth of nations: social, biological, and educational dynamics. New York: Guilford Press; 1999.

5. Britto PR, Lye SJ, Proulx K, Yousafzai AK, Matthews SG, Vaivada T, et al. Nurturing care: promoting early childhood development. Lancet 2017; 389:91-102.

6. Anderson LM, Shinn C, Fullilove MT, Scrimshaw SC, Fielding JE, Normand J, et al. The effectiveness of early childhood development programs. A systematic review. Am J Prev Med 2003; 24(3 Suppl):32-46.

7. Center on the Developing Child at Harvard University. A science-based framework for early childhood policy: using evidence to improve outcomes in learning, behavior, and health for vulnerable children. http://www. developingchild.harvard.edu (accessed on 29/ Jan/2019).

8. Schweinhart LJ, Montie J, Xiang Z, Barnett WS, Belfield CR, Nores M. Lifetime effects: the HighScope Perry Preschool study through age 40. Ypsilanti: HighScope Press; 2005. (Monographs of the HighScope Educational Research Foundation, 14).

9. Campbell F, Conti G, Heckman JJ, Moon SH, Pinto R, Pungello E, et al. Early childhood investments substantially boost adult health. Science 2014; 343:1478-85. 
10. Richter LM, Daelmans B, Lombardi J, Heymann J, Boo FL, Behrman JR, et al. Investing in the foundation of sustainable development: pathways to scale up for early childhood development. Lancet 2017; 389:103-18.

11. Tomlinson M, Hunt X, Rotheram-Borus MJ. Diffusing and scaling evidence-based interventions: eight lessons for early child development from the implementation of perinatal home visiting in South Africa. Ann N Y Acad Sci 2018; 1419:218-29.

12. Chartier MJ, Brownell MD, Isaac MR, Chateau D, Nickel NC, Katz A, et al. Is the families first home visiting program effective in reducing child maltreatment and improving child development? Child Maltreat 2017; 22:121-31.

13. Avellar SA, Supplee LH. Effectiveness of home visiting in improving child health and reducing child maltreatment. Pediatrics 2013; 132 Suppl 2:S90-9.

14. Peacock S, Konrad S, Watson E, Nickel D, Muhajarine N. Effectiveness of home visiting programs on child outcomes: a systematic review. BMC Public Health 2013; 13:17.

15. Issel LM, Forrestal SG, Slaughter J, Wiencrot A, Handler A. A review of prenatal home-visiting effectiveness for improving birth outcomes. J Obstet Gynecol Neonatal Nurs 2011; 40:157-65.

16. Dalziel K, Segal L. Home visiting programmes for the prevention of child maltreatment: costeffectiveness of 33 programmes. Arch Dis Child 2012; 97:787-98.

17. Gertler P, Heckman J, Pinto R, Zanolini A, Vermeerch C, Walker S, et al. Labor market returns to an early childhood stimulation intervention in Jamaica. Science 2014; 344:9981001.

18. Victora CG, Aquino EML, Carmo Leal M, Monteiro CA, Barros FC, Szwarcwald CL. Maternal and child health in Brazil: progress and challenges. Lancet 2011; 377:1863-76.

19. Instituto Brasileiro de Geografia e Estatística. Síntese de indicadores sociais: uma análise das condições de vida da população brasileira. Rio de Janeiro: Instituto Brasileiro de Geografia e Estatística; 2013.

20. Instituto Brasileiro de Geografia e Estatística. Pesquisa Nacional por Amostra de Domicílios: síntese de indicadores 2014. Rio de Janeiro: Instituto Brasileiro de Geografia e Estatística; 2015.

21. Organisation for Economic Co-Operation and Development. Education at a glance 2013: OECD indicators. Paris: Organisation for Economic Co-Operation and Development; 2013.

22. Gómez AMS. La contextualización del modelo de atención educativa no institucional cubano "Educa a tu Hijo" en países latinoamericanos. http://www.oei.es/inicialbbva/material/Edu ca_a_tu_Hijo_UNICEF_Siverio.pdf (accessed on 01/Aug/2017).

23. Schneider A, Ramires VR. Primeira Infância Melhor: uma inovação em política pública. Brasília: Organização das Nações Unidas para a Educação, a Ciência e a Cultura/Secretaria de Saúde do Estado do Rio Grande do Sul; 2007.
24. Mahalanobis PC. On the generalised distance in statistics. Proceedings of the National Institute of Sciences of India 1936; 2:49-55.

25. Instituto Brasileiro de Geografia e Estatística. Indicadores sociais municipais: uma análise dos resultados da amostra do Censo Demográfico de 2000. Rio de Janeiro: Instituto Brasileiro de Geografia e Estatística; 2000.

26. United Nations Children's Fund. The state of Brazil's children 2006. https://www.unicef. org/brazil/english/sbc_cdi.pdf (accessed on 01/Aug/2017).

27. Janus M, Offord D. Development and psychometric properties of the Early Development Instrument (EDI): a measure of children's school readiness. Can J Behav Sci 2007; 39:122.

28. Janus M, Brinkman S, Duku E. Validity and psychometric properties of the Early Development Instrument in Canada, Australia, United States, and Jamaica. Soc Indic Res 2011; 103:283-97.

29. Janus M, Duku E, Brinkman S, Dunkelberg E, Chianca T, Marino E. Socioemotional development and its correlates among 5-year-old children in Peru and Brazil. J Lat Am Stud 2014; 6:40-53.

30. Janus M, Duku E. The school entry gap: socioeconomic, family, and health factors associated with children's school readiness to learn. Early Educ Dev 2007; 18:375-403.

31. Guhn M, Gadermann AM, Hertzman C, Zumbo BD. Children's development in kindergarten: a multilevel, population-based analysis of ESL and gender effects on socioeconomic gradients. Child Indic Res 2010; 3:183-203.

32. Raskin M, Easterbrooks MA, Fauth RC, Jacobs F, Fosse NE, Goldberg JL, et al. Patterns of goal attainment among young mothers in a home visiting program. Appl Dev Sci 2017; 1-13.

33. Engle PL, Fernald LCH, Alderman H, Behrman J, O'Gara C, Yousafzai A, et al. Strategies for reducing inequalities and improving developmental outcomes for young children in lowincome and middle-income countries. Lancet 2011; 378:1339-53.

34. Filene JH, Kaminski JW, Valle LA, Cachat P. Components associated with home visiting program outcomes: a meta-analysis. Pediatrics 2013; 132 Suppl 2:S100-9.

35. Leer J, Lopez-Boo F, Expósito AP, Powell C. A snapshot on the quality of seven home visit parenting programs in Latin America and the Caribbean. Washington DC: Inter-American Development Bank; 2016. (Technical Note, IDB-TN-1083).

36. Hahn RA, Barnett WS, Knopf JA, Truman BI, Johnson RL, Fielding JE, et al. Early childhood education to promote health equity: a community guide systematic review. J Public Health Manag Pract 2016; 22:E1-8. 


\section{Resumo}

O planejamento e avaliação de programas de desenvolvimento na primeira infância (DPI) são pouco documentados em países de renda baixa e média. O objetivo deste estudo foi identificar características familiares e infantis associadas a desfechos do saúde desenvolvimental em crianças com idade de 4 a 6 anos que participaram do Primeira Infância Melhor (PIM), um programa de visitas domiciliares do Estado do Rio Grande do Sul, Brasil. Também avaliamos o impacto do PIM na vulnerabilidade no desenvolvimento no início da escolarização usando um grupo de comparação. Uma amostragem multi-etapas foi usada inicialmente para selecionar cidades, depois famílias, em diferentes regiões do estado, resultando numa amostra de oito cidades e 571 crianças (364 PIM; 207 comparação). Usamos um questionário sociodemográfico, respondido pelos pais, e o Instrumento de Desenvolvimento na Primeira Infância (EDI, em inglês), respondido pelos professores. Dentre as crianças do PIM, renda familiar mais baixa, tempo de saída do programa, cidade e menor idade estava associados a um risco maior de vulnerabilidade no desenvolvimento e/ou escores médios mais baixos nos domínios do EDI. A análise multivariada controlada por covariáveis não encontrou diferenças entre os grupos do estudo em termos dos desfechos do EDI, a despeito de as lacunas na equidade dos desfechos serem menores no grupo PIM. Esses resultados são discutidos no contexto dos desafios que programas de visitas domiciliares enfrentam para fazer frente às condições sociais complexas de famílias de alto risco e as dificuldades para encontrar um grupo de comparação adequado em comunidades onde um programa de DPI é universalmente acessivel. Também apontamos a importância de estabelecer sistemas de monitoramento estruturados e longitudinais em conjunto com a implementação de políticas de DPI.

Desenvolvimento Infantil; Saúde da Criança; Serviço de Assistência Domiciliar; Avaliação de Programas e Projetos de Saúde

\section{Resumen}

El diseño y evaluación de los programas para la infancia temprana (PIT) se han documentado escasamente en países de ingresos medios o bajos. El estudio tuvo como objetivo identificar familias $y$ características de niños, asociándolas con resultados en cuanto a la salud del desarrollo, con edades comprendidas entre 4 y 6 años de edad, que participaron en el programa "Primeira Infância Melhor" -PIM (Primera Infancia Mejor). Un programa de visitas a domicilio en el estado de Río Grande do Sul, Brasil. También se evaluó el impacto del PIM, en cuanto a la vulnerabilidad de su desarrollo tras entrar en la escuela, usando un grupo de comparación. En primer lugar, se utilizó un muestreo por etapas múltiples para seleccionar ciudades, luego familias en diferentes regiones del estado, dando como resultado una muestra de ocho ciudades y 571 niños (364 PIM; 207 en el grupo de comparación). Se usó un cuestionario sociodemográfico, cumplimentado por los padres, y el Instrumento de Desarrollo Temprano (EDI, en inglés), completado por los profesores. Niños en el PIM, en familias con ingresos bajos, tiempo desde su salida del programa, ciudad, y contar con menor edad, estuvieron asociados con un riesgo más alto respecto a la vulnerabilidad del desarrollo $y / o$ con puntuaciones promedio más bajas en el ámbito del EDI. El análisis multivariado al realizar controles de las covariables no encontró diferencias entre los grupos de estudio en los resultados EDI, incluso a pesar de las brechas, respecto a la equidad de los resultados, que fueron más pequeñas en el grupo PIM. Estos resultados se discutieron en el contexto de los desafíos a los que se enfrentan los programas de visitas a hogares, dirigidos a familias en condiciones sociales complejas de alto riesgo y con dificultades para encontrar un grupo de comparación, adecuado en comunidades, donde un programa PIT fuera accesible universalmente. También resaltamos la importancia de establecer sistemas estructurados y longitudinales de supervisión junto a la implementación de políticas PIT.

Desarrollo Infantil; Salud del Niño; Servicios de Atención de Salud a Domicilio; Evaluación de Programas y Proyectos de Salud
Submitted on 28/Dec/2017

Final version resubmitted on 02/Aug/2018

Approved on 17/Aug/2018 